Portland State University

PDXScholar

\title{
Witchcraft and the Performance of Womanhood in L.M. Alcott's Behind a Mask
}

Jovian M. Davis

Portland State University

Follow this and additional works at: https://pdxscholar.library.pdx.edu/honorstheses

\section{Let us know how access to this document benefits you.}

\section{Recommended Citation}

Davis, Jovian M., "Witchcraft and the Performance of Womanhood in L.M. Alcott's Behind a Mask" (2017). University Honors Theses. Paper 480.

https://doi.org/10.15760/honors.479

This Thesis is brought to you for free and open access. It has been accepted for inclusion in University Honors Theses by an authorized administrator of PDXScholar. Please contact us if we can make this document more accessible: pdxscholar@pdx.edu. 


\section{Witchcraft and the Performance of Womanhood in L.M. Alcott's Behind a Mask By Jovian Davis \\ Advised by Dr. Hildy Miller}

The Coventry family's new governess seems like the ideal Victorian middle class woman-meek, plain but not ugly, skilled in the art of women's work and parlor entertainment, and knows her place at the intersection of class and gender. However, the reader soon learns that she isn't who she says she is. Rather than a 19 year old respectable governess, she is a 30 year old divorced actress seeking the economic security of a wealthy husband. In Louisa May Alcott's Behind a Mask, or, A Woman's Power, protagonist and femme fatale Jean Muir uses her woman's power (equal parts sexuality, perceptiveness, and ability to perform both her class and gender), and perhaps a little bit of witchcraft, to manipulate the family where she serves as governess, and wile the wealthy, titled man of the house into marrying her, all before the family discovers her past. To do this, she exhibits incredible skill at performing the strict gender roles of the time. She is, at first, quiet and passive, not too attractive, and mysterious enough to make the men come to her. She knows how to find and use each man's fatal flaw, manipulating them into professing their love for her before deciding their fate.

I am interested in gender as a performance in the text, and witchcraft both as a subversion of and a tool of this performance. At times, Muir's supernatural power seems in conflict with her womanly persona. At other times, it seems like a natural extension of her femininity, as if qualities of witchcraft are simply heightened qualities of womanhood. In this paper I will explore these relationships by examining particularly 'witchy' and gendered moments of the text. I will also consider any potential implications of this performance of gender. The performance of womanhood is a social and economic necessity, a performance that never ends, which leads me to wonder what effects this has on women's sense of self. However, Muir isn't 
simply performing out of necessity, she also seeks to teach the Coventrys a lesson. My goal is to reconcile an analysis of both Muir's external (social and financial) and internal (malicious) motivations.

I argue that Muir is endowed with supernatural abilities, and that these abilities allow her to perform what I have coined a false unmasking, where she pretends to reveal a part of her inner self but is actually revealing a mask behind a mask. This tactic is essential to her performance of womanhood and therefore her survival. I explore these concepts in the text by analyzing moments of the supernatural and of false unmasking in the text. This analysis led me to consider what these skills, tactics, and performances allow Muir to do, and what the reader's relationship is to that performance. In this project, I will discuss the novella's use of the supernatural, then instances of false unmasking, before considering the implications of this research.

Before beginning my analysis, I'll include a brief summary of the novella. The story is set in Victorian-era England, where the wealthy Coventry family gets a new governess named Jean Muir. Muir seems like the perfect governess; nineteen, meek, and skilled in the art of homemaking. On the first night, Muir retreats to her room and 'unmasks' herself for the reader as the divorced 30 year-old actress she is. She removes her makeup, false teeth, and wig, pours herself a cocktail, and says to herself, "[T]he curtain is down, so I may be myself for a few hours, if actresses ever are themselves" (14). She quickly wins the favor of all in the house, causing the younger brother Ned to confess his love for her and jealously attack his older brother Gerald. Gerald sends Ned out of the house to get him away from Muir. Then, Muir wins Gerald over when the family engages in a day of tableaux performances. Gerald soon breaks off his engagement to his cousin Lucia who lives with the family, and proposes to Muir, who says that she will consider his offer. 
Muir must marry soon, as Ned has learned about her secret identity and threatened to reveal it if she doesn't leave voluntarily. Muir then goes after Sir John, who not only proposes but agrees to marry her two days later in secret. Ned returns to the family, in possession of the shocking correspondence between Muir and a friend, that detail her plan to marry into the family and teach them all a lesson as she does. The family reads the letters aloud, humiliated and furious, when Jean Muir and Sir John walk into the room as husband and wife. Sir John, enamored, doesn't believe the family, and as they try to convince him of her secret, Muir throws the letters in the fire. The entire family is now forced to maintain the secret, for if they ruin Muir's name they would ruin their own as well. Thus, Muir ensures her survival and wealth, and humbles the Coventry family in the process.

Behind a Mask is just one of Alcott's many texts that were published under a pseudonym before Little Women, to be later recovered, compiled, and republished by Madeleine Stern in 1975. Many literary critics have drawn biographical connections between Alcott's early pseudonymous texts and Little Women, linking Alcott's experiences to her protagonists. Judith Fetterley argues in her essay, "Impersonating Little Women”, that writing itself is something of a performance for Alcott, meaning that she often wrote out of a financial desperation that reveals itself in Alcott's work. Fetterley writes, "Behind a Mask asserts that there is no honest way for woman to make a living; survival depends on one stratagem or another—sell your hair, sell your body, sell your soul; all are equivalent moves in the same game" (Fetterley, 2). In this reading, Alcott and her leading ladies engage these strategies and perform womanhood in order to survive. Fetterley asserts that Muir's performance is that of the little woman, who is prim and proper, agreeable, modest, and skilled in the art of homemaking. The little woman is someone who "can do it all, who can be all things to all people." 
Fetterley goes on to assert that "the successful 'little woman' is a superwoman... Further, since the role clearly requires an extraordinary level of consciousness, any illusion about its being the natural expression of essential femininity is also exploded" (Fetterley, 3). Fetterley here points out that no natural, normal, human woman can do what Muir does. However, Fetterley has failed to address the resulting question: if this role is a fantasy, unnatural (or supernatural), then what is it that enables Muir to perform it so well? I argue that Alcott has covertly endowed Muir with witch-like qualities and a supernatural sense, an ability to read people, heal them, be all things to all people, and enchant the Coventry family, thus ensuring her survival in a sexist, capitalist society.

The presence of the supernatural is a rich but largely unexplored element of Behind a Mask. Theresa Strouth Gaul is one critic who has considered this, and she explores it in her essay “Trance-Formations: Mesmerism and 'A Woman's Power' in Louisa May Alcott's Behind a Mask". Gaul describes Muir's powers as mysticism, which was hugely popular in the United States at the time that the novella was written, and which Alcott herself had a personal experience with. As Gaul writes, "Alcott grants her heroine the traits indelibly associated with mesmerism in the nineteenth century: a piercing gaze, the ability to provoke physical sensations, and a mysterious power to conform others' wills to her own." In this reading, these mesmeric powers not only allow Muir to seduce the entire household, but allow Alcott the necessary language to safely describe Muir's "womanly power", that being her sexuality. Although Gaul certainly presents a convincing explanation for the bewitching language in the text, I assert that the effect of the enchanting words that surround Muir extend far beyond her sexual power, in allowing her to not only use her "woman's power" of sexuality, but in fact to perform womanhood. 
Jean Muir's success in her plot to gain control of the Coventry household and ensure her economic security is dependent on her various supernatural methods of deceiving the household. These consist of her powers of extreme perceptiveness (a "sixth sense"), hypnotism, shapeshifting and disguise, and healing. Although the reader never gets any explicit confirmation that Muir possesses supernatural gifts or is performing witchcraft, Muir is shrouded in mystery, the uncanny, and otherworldliness; she is constantly one step ahead of the other characters, is described in distinctly witch-like language, and is generally unbound by the strict rules of the natural world.

Before Muir even makes her first entrance, Gerald jokes about the new governess "bewitching" Ned, setting the tone for Muir's enchanting interactions with the men (3). When she does arrive, the timing is uncanny—just as Mrs. Coventry complains of Muir's tardiness, the clock strikes seven and the doorbell rings (3). Muir arrives at exactly the right time, not early and not late, just as Mrs. Coventry was beginning to complain. The simultaneous chiming of bells from the clock and the door feels ominous, and is the first of several occurrences of Muir's strangely impeccable timing.

In this first meeting with the family, Muir reads all of the family members' fatal traits, determining that Gerald only wants what he can't have, while his fiancée Lucia is jealous and proud. She sets her scheme of seduction in motion with one contemptuous look at Gerald. Gerald "experienced a new sensation, indefinable, yet strong...Lucia saw it, and hated Miss Muir with a sudden hatred... Coventry was himself again in an instant, with no trace of that passing change, but a look of interest in his usually dreamy eyes, and a touch of anger in his sarcastic voice" (8). The immediacy of this change is what makes is so uncanny and supernatural. Muir, who isn't attractive and who before this moment Gerald had blatantly 
ignored, awoke feelings in Gerald that he had never felt before and that he couldn't describe-all in an instant, with one hypnotic look. She set her whole plan in motion with one angry glance, expressing dislike for Gerald in order to provoke his major character flaw of indifference and pride. This is what causes Gerald to take interest in Muir: he thinks that she hates him which makes her all the more desirable. Meanwhile, Lucia's intense jealousy has been triggered, which causes her to cling closely to Gerald, which makes her repulsive to him, therefore driving him into Muir's arms. This is the first of several moments where Muir uses her gaze to control the men, a tactic that is very evocative of mesmerism or hypnotism and which exerts her power over the men.

The language used to describe Muir's supernatural power over the men lends Alcott the language she needed to describe Muir's sexual power, as we see in this scene and others and as Gaul discussed. Muir obviously has sexual power; she is able to control each and every man in the house, even Gerald, whose heart is "so fast asleep no woman has had power to wake it yet" (144). The language for the supernatural can be read as parallel to sexual language: it shows a woman's power and Muir's influence over the men; the descriptions of the men as "enchanted", "charmed", and "bewitched" reveal their loss of agency.

Days or weeks later, Ned has confessed his love for Muir in front of Gerald, and asks her to run away with him. As Ned awaits an answer, Muir looks from one brother to the other, and "neither brother could have explained why that hurried glance affected them as it did, but each felt conscious of a willful desire to oppose the other" (48). After Muir says that she loves someone else (without specifying whom), Ned reaches out to her and "she seemed to fear a blow, for suddenly she clung to Gerald with a faint cry. The act, the look of fear, the protecting gesture Coventry involuntarily made were too much for [Ned]" (50). He grabs a knife and delivers a 
blow that would have been fatal had Gerald not blocked it with his arm. A few days later, Ned leaves home as a result of the incident. Again we see the strong effect of Muir's gaze on the men around her: with a quick glance between the two brothers, she has the power to provoke them to physically fight each other. With one look, she pits them against each other and completely transforms both of their demeanors. Ned transforms from being soft spoken and passive to a violent and impulsive man, and Gerald goes from actively ignoring Muir to being her knight in shining armor. Muir's power to control and manipulate others with her gaze can only be described as hypnotic.

Gerald's arm is bleeding badly and Muir springs into action, immediately knowing how to stop the bleeding, while Ned becomes faint and doesn't know what to do. Her efforts save Gerald's life. She brings salts, water, and wine to help Gerald regain strength, and helps him to his room. Her ability is useful, but out of place for a young and meek governess. When Muir visits Gerald later, she has an ethereal quality about her:

[A]ll in white, with no ornament but her fair hair, and a fragrant posy of violets in her belt, she looked a different woman from the meek, nun like creature one usually saw about the house. Her face was as altered as her dress, for now a soft color glowed in her cheeks, her eyes smiled shyly, and her lips no longer wore the firm look of one who forcibly repressed every emotion. A fresh, gentle, charming woman she seemed. (56) Muir certainly has mastered the art of transformation, perhaps even shapeshifting. Her previous appearance is described as nun-like, implying chastity and sexual unavailability, while her youthful bride-like appearance indicates beauty and sexual availability. Then, she lulls him to sleep. She sings him "a dreamy, low-toned lullaby", which soothed the listener "like a spell," then she takes his hand: "a subtle warmth seemed to steal from the soft palms that enclosed his 
own... [he] seemed to sink into a soft cloud... sleep, deep and dreamless, fell upon him, and when he woke, daylight was shining in between the curtains, his hand lay alone on the coverlet, and his fair-haired enchantress was gone" (59).

Gerald seems hypnotized; he feels as if he's sinking into a cloud, his mind is wandering, and his memory is fuzzy the next day. Words like "spell" and "enchantress" being used alongside descriptions of Muir lulling Gerald into a deep sleep merely with her touch gives the reader a sense of Muir's supernatural persona. She hypnotizes him using song, gaze, and touch, and once he is under her spell, she disappears.

Muir's sense of the supernatural allows her to use a tactic that I call a false unmasking, which she uses throughout her conspiracy. She pretends to reveal a part of her true identity, but is actually revealing a mask behind a mask in order to manipulate their perception of her while simultaneously giving the impression of vulnerability and authenticity. I'll go through several examples of her use of this tactic. In her first meeting with the Coventry family, eldest son Gerald and his fiancée/cousin Lucia are talking about Muir across the room, and Gerald reveals his mistrust of Muir when he says to Lucia, "Scene first, very well done," implying that he sees through Muir's act. Muir overhears him, replying, "The last scene shall still be better" (8). The remark is at once threatening and premonitory-Muir seems to know how her scheme will end. The next morning, while wandering about the property near Sir John's home, she senses him approaching even before the reader does: "Suddenly her whole air changed, she pushed back her hat, clasped her hands loosely before her, and seemed absorbed in girlish admiration of the fair scene that could not fail to charm any beauty-loving eye. The cause of this rapid change soon appeared." The cause, of course, is Sir John (16). She is never described as actually seeing Sir John before the reader does, she just intuitively knows that he is watching. 
Later, Muir tames Ned's uncontrollable horse by using the exact same tactic on the horse as she does on the men - all while knowing she is being watched by Ned. Muir offers it some clover before realizing that the horse will not come to her willingly:

She began to pull daisies, singing idly the while, as if unconscious of the spirited prancings of the horse...by degrees and with much coquetting, the horse permitted her to stroke his glossy neck and smooth his mane. It was a pretty sight—-the slender figure in the grass, the high-spirited horse bending his proud head to her hand. (20) Instead of showing the horse that she wants his attention, she ignores him, singing and making flower chains. This lures the horse in, he is intrigued, and "nibbles" her and smells her "little foot", as she "uttered caressing words" and makes "soothing sounds". If the sexual language here wasn't obvious enough yet, Muir is described as "coquetting" before eventually petting the horse as he "[bends] his proud head to her hand," literally bowing to her. The reader then learns that Ned has been watching all along, which Muir likely knew already, and Ned is rather charmed that she was able to win over his horse. This, in turn, wins Ned over. Muir says to him of the horse, "[Y]our grooms did not know how to win his heart, and so subdue his spirit without breaking it" (20).

This tactic, of elaborately performing femininity while pretending not to know she is being watched, is one she repeats again and again. She bolsters Lucia's pride by admiring a painting of her mother knowing that Lucia is watching (23), elicits Sir John's pity by bursting into tears when he is watching from another room (34), and enchants Gerald by looking "most womanly and winning" while embroidering and singing to herself in the garden (104).

These smaller moments reveal her overall strategy: by pretending not to know she is being watched, she can lead these men to believe that they are seeing a glimpse of her "true" 
self. She reveals some carefully constructed secrets and traits, they think they've seen the real Jean Muir, and then stop looking for more. Muir seems to have many versions of herself, the "little woman" version she initially presents, the coy love interest version she selectively shows Gerald, the dutiful daughter she plays for Sir John, and the version that the reader sees, who is a divorced 30 year-old actress. Due to Muir's contemporary gender expectations, she can't express herself in front of the men; but by pretending to not know she is being watched, she can flirt without being a coquette, be beautiful without being vain, and be pitied without seeming pathetic. This is her primary tool in seducing first Ned, then Gerald, and eventually Sir John. This strategy of a false unmasking is one example of how Muir's sense of the supernatural aids her in performing womanhood. By always sensing what and who is around her, she can manipulate how she is perceived, ensuring that she never slips out of character and does something unwomanly. It also protects her true identity, as the men think that this second mask is indeed her true self, and don't bother to dig any deeper. However, this also raises the question, what is Jean Muir's true self, if she has one? Does the reader have access to Muir's true identity? This is a concept that I will address later in my essay.

In one of the most pivotal sections of the text, the family engages in a day of tableaux scenes, a popular Victorian pastime where friends and family members dress up and pose as famous paintings in a still-life. This is the day where Jean Muir executes her seduction of Gerald, and the tableaux performances play a key role in this. Muir and Gerald are to appear in a scene together. In the scene, a young woman is hiding her lover behind her mantle; he kneels before her and they embrace. The intimacy of the moment, however false, transforms Gerald and his feelings for Muir: 
Many women had smiled on him, but he had remained heart-whole, cool, and careless, quite unconscious of the power which a woman possesses... Now, as she knelt there with a soft arm about him, a slender waist yielding to his touch, and a maiden heart throbbing against his cheek, for the first time in his life he felt the indescribable spell of womanhood. (77)

Next, they do a scene where the same couple has been discovered by their pursuers; the young woman has been shot and rests her head on her lover's chest as she dies.

The power of those tender eyes thrilled [Gerald] with a strange delight, and set his heart beating as rapidly as hers had done. She felt his hands tremble, saw the color flash into his cheek, knew that she had touched him at last, and when she rose it was with a sense of triumph which she found it hard to conceal. (77)

Gerald is completely transformed by these two scenes. Before, he was cool and indifferent, but Muir stirred in him a passion that he didn't know existed and doesn't know how to hide. In an earlier scene that Muir did without Gerald, he felt as if he "saw a glimpse of the truth" in her acting. To Gerald, Muir's acting is so real that he doesn't believe she is acting at all, but simply revealing a part of herself that she otherwise wouldn't. She awoke him to a woman's power; in their brief moment of theatricized intimacy, he becomes hypnotized, he believes that they are the roles that they play. The indifference, hesitation, and innocent blush she feigns before the curtains open set her plan in motion because Gerald only wants what he can't have. Then, as they embrace and play the part of lovers, he falls under the indescribable spell of womanhood. 
Toward the end of the novella, When Ned threatens to expose Muir, she has no choice but to expedite her plan of marriage, and needs for Sir John to propose. Muir is reading to Sir John, which she does daily, and he leaves the room for a moment. Knowing that he is watching her, Muir looks at a picture of Sir John on the mantle, and "as if obeying an irresistible impulse, she took it down, looked long and fondly at it, then, shaking her curls about her face, as if to hide the act, pressed it to her lips and seemed to weep over it like an uncontrollable paroxysm of tender grief." Yet again she falsely unmasks herself by pretending to not know she is being watched. This allows her to convey her love for Sir John without having to be too forward, which would have been inappropriate and ineffective. As Muir previously said to herself, "How can I make him understand, yet not overstep the bounds of maiden modesty?" (119) Every facial expression and motion here is carefully choreographed: she looks at the photo as if on an impulse, as if it was beyond her control and coming from a place of repressed desire. She shakes her hair around her face out of shame, further distancing herself from the act and protecting her pure image. The act is modest, tender, pathetic, saccharine, and sentimental; no more than an exaggeration of what men think that women are like in private. Her carefully calculated performance results in the quick and secret marriage that she is after.

This tactic, of elaborately performing femininity while pretending not to know she is being watched, is one she repeats again and again. She bolsters Lucia's pride by admiring a painting of her mother knowing that Lucia is watching, elicits Sir John's pity by bursting into tears when he is watching from another room, and enchants Gerald by looking exaggeratedly feminine while embroidering and singing to herself in the garden. By pretending not to know she is being watched, she can lead these men to believe that they are seeing a glimpse of her true self. When they believe they have figured her out, they stop looking for more. Muir can't 
express herself in front of the men; but by pretending to not know she is being watched, she can flirt without being immodest, be beautiful without being vain, and be pitied without being pathetic. In fact, this tactic only works because the men are so willing to believe that Muir is a simple creature with no real complexity. They don't expect there to be more to her than they can see, so when what she reveals to them reinforces their preexisting beliefs about women, they are eager to accept it and don't think to look any deeper, which protects her true identity.

However, do we really know who Jean Muir is? On the first reading, the reader thinks they know everything about her-they take their glimpses of Muir when she's alone at face value. However, there is reason to believe that Muir isn't even showing the reader the whole story. For example, at the end we learn that Muir has been writing accounts of her exploits in letters to a friend, where she reveals quite a bit of malice towards the Coventrys and a longstanding plan to not only marry into the family, but teach them all a lesson as she does itsomething that the reader isn't aware of until this point. Additionally, the reader knows very little about Muir and doesn't have any insight into her thoughts, as the narration is in a limited third-person style. We get glimpses of her motivations when she is alone and talking to herself, but these moments are few and far between. We know nothing of Muir's past besides what she reveals in letters to her friend, but if her friend is willing to sell their private correspondence to Ned, how close of a friendship can it be? As a result, the insight provided in the letters is limited at best.

The reader essentially knows nothing about Muir outside of the context of the Coventry home. We first see her when she enters the home and the story ends in the home. It's uncanny, almost as if she doesn't exist outside of the Coventry household. Her entire role in the home is an elaborate performance. For all we know, Muir may be so consumed by her performance and 
her scheme that she has no true self, or that her true self is so buried that she may even be performing when she is alone. Jean Muir is likely not even her real name. As post-modern readers, we might be inclined to conclude that Muir, like all of us, has many different versions of herself that she presents to the outer world, and even when she is alone.

Muir herself alludes to this issue when she is first alone in her new room and "unmasks" herself for the reader, saying to herself, "[T] he curtain is down, so I may be myself for a few hours, if actresses ever are themselves" (14). This reflects a larger theme in the text, that of the self - if you spend a certain amount of time acting, pretending to be someone else, the distinction between performance and self becomes blurred. Muir has constructed an elaborate and layered persona, constantly calculating what role to play and when-it seems all too likely that the boundaries between these roles would become muddy. Muir either has buried her "true self" to eliminate the risk of revealing her secret, or Muir never reveals her true self to the narrator and reader. The effect is the same either way - the reader feels alienated. Whether they recognize the dynamics at play or not, lack of access to Muir's inner thoughts and private moments makes her less relatable and add to the sense of the mysterious or abnormal.

Muir certainly creates her mask (or masks) out of financial desperation; there would have been no other options for a divorced lower-middle class woman. However, there seem to be other motivations at play here. If she only cared about survival, she would have married Ned rather than Gerald or Sir John, as she reveals in one of her letters (145). When she first walks about the Coventry property to which Gerald is heir, she says to herself, "Not bad... but the other may be better, and I will have the best," referring to Sir John's estate (16). Muir exhibits a kind of capitalistic greed here atypical of the sentimental little woman. Muir wants the best regardless of how she feels about each of the men, and the best is Sir John, with his title, property, and 
money. Marriage to Ned would make her a wife, marriage to Gerald would make her mistress of the estate, but marriage to Sir John makes her a lady.

Jean Muir's motivations are most apparent in the letters that she writes to her actress friend, which she writes throughout her time with the Coventry family and which are acquired by Ned (and revealed to the family and the reader) after he learns of Muir's secret identity. In her first letter, written a few days after her arrival, she writes, "[Gerald] is well worth winning, but I prefer the title, and as the uncle is a hale, handsome gentleman, I can't wait for him to die," revealing her raw ambition, not for merely survival, but for social capital. Additionally, she reveals multiple times throughout the text that she wants to not only marry Sir John, but cause as much chaos as possible in the process, and she seems to take a cathartic sense of joy in that chaos. In that first letter, she writes of her first impression of the Coventry family: "They are an intensely proud family, but I can humble them all I think, by captivating the sons, and when they have committed themselves, cast themselves off, and marry the old uncle, whose title takes my fancy" (143). This encapsulates Muir's plan, which she successfully executes by winning over first Ned, then Gerald, then Sir John. In another letter, she writes that Gerald "has proven himself false to brother, mistress, and his own conscience," describing how Gerald broke his promise not to pursue Jean Muir, ending his engagement with Lucia to propose to Jean Muir, who has secured the proposal of Sir John and will reject Gerald. Thus, she exacts revenge on Gerald and Lucia simultaneously.

Ned, after reading all the letters aloud to the family at dinner, tells them that he has forced Muir away from the home and that they are safe. In fact, she has just married Sir John in secret at his home. Ned, believing that they are rid of Jean Muir, says that the family should "leave this dangerous woman to the fate which will surely overtake her." Then, a seemingly 
disembodied voice says, “'Thank you, it has overtaken her, and a very happy one she finds it.' A soft voice uttered the words, and an apparition appeared at the door, which made all start and recoil with amazement_Jean Muir leaning on the arm of Sir John” (149).

She has executed her plan, and now that she is a Coventry, she is untouchable - they can't speak badly of her because it would reflect badly on the family; even more so now that she is married to the head of their family. The family tries to convince Sir John that Muir isn't who he thinks she is, and as they turn to have him read the letters, Muir releases a cackle by the fire as the letters burned: "the mocking laugh, the sudden blaze, showed what had been done" (151). The sleight-of-hand and opportunism required to burn the letters, the flash of sudden flames, and the menacing cackle reveal Muir's final act of witchcraft, burning the evidence of her past and her plot. Literary critics and the reader wants to absolve her of guilt because this reinforces our cultural belief that women are always good and always victims, but this robs Muir of her agency. To absolve Muir of guilt in this way, to blame her actions on her surroundings and ignore her greed and malice, is to perform an irresponsible and short-sighted reading. We should read Muir as the protagonist that she is: witch and femme fatale. So, without pretending that Jean Muir is merely a victim, this text can offer us some fascinating insight into gender, performance, and identity, and provoke thought about the relationship between the two. Somehow, as readers, we have to reconcile that on one hand Muir acts to survive, while on the other hand she absolutely relishes in the humiliation and chaos that she causes. Perhaps that reconciliation lies in the fact that we know just as much about our femme fatale as the Coventry family does, and are therefore washed of our responsibility to judge the actions of the woman and witch that we know as Jean Muir. 


\section{Works Cited}

Dawson, Melanie. “A Woman's Power: Alcott's 'Behind a Mask' and the Usefulness of Dramatic Literacies in the Home.” American Transcendental Quarterly 11.1 (1997): 1940. Print.

Elliott, Mary. "Outperforming Femininity: Public Conduct and Private Enterprise in Louise May Alcott's Behind a Mask.” American Transcendental Quarterly 8.4 (1994): 299-310. Print.

Fetterley, Judith. "Impersonating 'Little Women': The Radicalism of Alcott's 'Behind a Mask.'” Women’s Studies: An Interdisciplinary Journal 10.1 (1983): 1-14. Print.

Fetterley, Judith. “'Little Women': Alcott's Civil War.” Feminist Studies 5.2 (1979): 369-383. JSTOR. Web.

Garrison, Laurie. Science, Sexuality and Sensation Novels: Pleasures of the Senses. Basingstoke, Hampshire ; New York, NY: Palgrave Macmillan, 2011. Print.

Gaul, Theresa Strouth. “Trance-Formations: Mesmerism and 'A Woman's Power' in Louisa May Alcott's Behind a Mask.” Women's Studies: An Interdisciplinary Journal 32.7 (2003): 835-851. Print.

Kaledin, Eugenia. "Louisa May Alcott: Success and the Sorrow of Self-Denial." Women's Studies 5.3 (1978): 251. Print.

Schewe, Elizabeth. "Domestic Conspiracy: Class Conflict and Performance in Louisa May Alcott's 'Behind a Mask."” American Transcendental Quarterly 22.4 (2008): 577-592. Print.

Smith, Gail K. "Who Was That Masked Woman? Gender and Form in Louisa May Alcott's Confidence Stories." American Women Short Story Writers: A Collection of Critical Essays. Ed. Julie (ed.) Brown. xxx, 367 . New York: Garland, 1995. 45-59. Print. Garland Reference Library of the Humanities (GRLH): 1737. 